\title{
Penyelesaian Sengketa Kewenangan Lembaga Negara Independen di Indonesia
}

\author{
Kelik Iswandi ${ }^{1 *}$, Nanik Prasetyoningsih ${ }^{2}$ \\ 1, ${ }^{2}$ Fakultas Hukum Universitas Muhammadiyah Yogyakarta, Yogyakarta, Indonesia \\ *E-mail: kelik.iswandi.2016@law.umy.ac.id
}

Dikirim: 11/05/2020

\begin{tabular}{l}
\hline Info Artikel \\
\hline \\
Keywords: \\
Competence Dispute; \\
Constitutional Court; \\
Independent State \\
Organ.
\end{tabular}

\section{Kata Kunci:}

Lembaga Negara Independen; Mahkamah Konstitusi; Sengketa Kewenangan.

\section{DOI:}

10.47268/sasi.v26i4.283

\begin{abstract}
Direvisi: 21/09/2020
Abstract several times in Indonesia has an impact on obstruction of competence. Several cases of competence dispute which involve independent state organ have been submitted to the Constitutional Court but not all have been granted. This study aims to examined the concern of competence dispute which involves independent state organ and factors of independent state organ can fulfill the subjectum litis criteria of SKLN in Constitutional Court. The research method is normative by using primary, secondary, and tertiary legal materials, collected from library research. This research analytical data use the statute approach and case approach. The results of this study indicate that the authority of the Constitutional Court does not specifically regulate state institutions that can be subjectum Litis SKLN in the Constitutional Court, there is a gap accommodated by the Constitutional Court in several decisions.
\end{abstract}

Dipublikasi: 20/12/2020

Abstrak
Sengketa kewenangan lembaga negara independen beberapa kali terjadi
di Indonesia yang berdampak terhadap terhambatnya pelaksanaan
kewenangan. Beberapa kasus sengketa kewenangan lembaga negara
yang melibatkan lembaga negara independen telah diajukan ke
Mahkamah Konstitusi tetapi tidak semua dikabulkan. Penelitian ini
bertujuan untuk mengkaji penyelesaian sengketa lembaga negara
independen dan faktor-faktor lembaga negara independen yang
memenuhi kriteria subjectum litis SKLN di Mahkamah Konstitusi.
Penelitian ini merupakan penelitian normatif yang dilakukan dengan
mengkaji bahan hukum primer, sekunder, dan tersier yang diperoleh dari
studi pustaka. Analisis data dalam penelitian ini menggunakan
pendekatan perundang-undangan dan pendekatan kasus yang
menghasilkan penelitian deskriptif analitik. Hasil penelitian ini
menunjukan bahwa kewenangan Mahkamah Konstitusi tidak secara
rinci mengatur lembaga negara yang dapat menjadi subjectum litis
SKLN di Mahkamah Konstitusi, terdapat celah yang diakomodir oleh
Mahkamah Konstitusi dalam beberapa putusan.




\section{A. PENDAHULUAN}

Kekuasaan yang diberikan kepada lembaga negara sifatnya saling membatasi antara yang satu dengan yang lain (checks and balances) ${ }^{1}$. Pasal 1 ayat (3) Undang-Undang Dasar 1945 menyatakan bahwa Indonesia merupakan negara hukum. Dalam konsepsi negara hukum terdapat prinsip pembagian atau pemisahan kekuasaan. Dalam melaksanakan kekuasaan dalam suatu negara terdapat lembaga negara. Di Indonesia terdapat beragam jenis lembaga negara, salah satunya ialah lembaga negara independen.

Lembaga negara independen lahir dengan fungsi dan tugas ketatanegaraan yang bersifat khusus. Beberapa ahli berbeda pendapat terkait dengan kedudukan lembaga negara independen. Hal ini dikarenakan tidak terdapat patokan khusus yang diberikan oleh pembentuk lembaga negara independen terkait dengan kedudukannya dalam struktur ketatanegaraan di Indonesia. Ketidakjelasan kedudukan tersebut membuat lembaga negara independen terlibat dalam beberapa sengketa kewenangan.

Salah satu kasus sengketa kewenangan yang melibatkan lembaga negara independen ialah sengketa kewenangan antara Komisi Pemilihan Umum dan Pemerintah Provinsi Papua. Obyek sengketa dalam kasus sengketa kewenangan antara Komisi Pemilihan Umum dan Pemerintah Provinsi Papua ialah terkait dengan penyelenggaraan pemilukada pada daerah otonomi khusus dalam hal ini Provinsi Papua. Kasus ini telah diselesaikan di Mahkamah Konstitusi dengan register perkara No. 3/SKLN-X/2012. Mahkamah Konstitusi mengabulkan permohonan tersebut dan menyatakan bahwa baik pemohon dan termohon memenuhi dapat menjadi pihak dalam SKLN (subjectum litis).

Sengketa yang melibatkan lembaga negara independen berikutnya ialah sengketa kewenangan Antara Komisi Penyiaran Indonesia dengan Presiden Republik Indonesia c.q Menteri Komunikasi dan Informatika. Obyek sengketa dalam kasus tersebut ialah kewenangan pemberian izin penyelenggara penyiaran dan pembuatan aturan dalam hal penyiaran. Kasus ini diregister oleh Mahkamah Konstitusi dengan Nomor 030/SKLNIV/2006. Mahkamah Konstitusi menolak permohonan tersebut dan menyatakan bahwa Komisi Penyiaran Indonesia tidak memenuhi syarat subjectum litis.

Dalam dua kasus tersebut para pihak pemohon merupakan lembaga negara independen. Akan tetapi, terdapat perbedaan putusan terkait dengan terpenuhinya syarat subjectum litis. Berdasarkan 24C ayat (1) dan (2) Undang-Undang Dasar 1945 jo. Pasal 61 ayat (1) UndangUndang Pasal Nomor 24 Tahun 2003 tentang Mahkamah Konstitusi jo. Pasal 2 Peraturan Mahkamah Konstitusi Nomor 08/PMK/2006 tentang Pedoman Beracara dalam Sengketa Kewenangan Konstitusional Lembaga Negara telah melimitasi lembaga negara yang dapat menjadi pihak yang berperkara (subjectum litis) dalam SKLN di Mahkamah Konstitusi. Lembaga-lembaga tersebut ialah:

a) Dewan Perwakilan Rakyat;

b) Dewan Perwakilan Daerah;

c) Majelis Permusyawaratan Rakyat;

d) Presiden;

e) Badan Pemeriksa Keuangan;

f) Pemerintah Daerah; atau

g) Lembaga negara lain yang kewenangannya diberikan oleh UUD 1945.

Dalam ketentuan tersebut, lembaga negara yang dapat menjadi pihak dalam SKLN telah

1 Eddyono, L. W., (2010), "Penyelesaian Sengketa Kewenangan Lembaga Negara oleh Mahkamah Konstitusi", Jurnal Kostitusi, 7 (3): 1-48, h. 39. 
terlimitasi. Akan tetapi pada perkara No. 3/SKLN-X/2012, Mahkamah Konstitusi berpendapat Komisi Pemilihan Umum memenuhi syarat sebagai subjectum litis. Secara langsung Komisi Pemilihan Umum bukanlah lembaga negara yang disebutkan dalam Pasal 2 PMK Nomor 08/PMK/2006. Hal ini dikarenakan Komisi Pemilihan Umum merupakan lembaga negara independen bukan lembaga negara yang diatur secara detail oleh konstitusi. Akan tetapi, Komisi Pemilihan Umum memiliki kewenangan yang ditegaskan dalam Undang-Undang Dasar 1945. Oleh karena itu, Mahkamah Konstitusi berpendapat bahwa Komisi Pemilihan Umum memenuhi syarat subjectum litis. Lantas sejauh manakah lembaga negara independen yang dapat menjadi subjectum litis dalam SKLN di Mahkamah Konstitusi? Apakah hanya terbatas pada Komisi Pemilihan Umum atau masih terdapat lembaga negara lain yang dapat menjadi subjectum litis?

Terkait dengan lembaga negara yang dapat menjadi subjectum litis, Jimly Asshiddiqie berpandangan selain lembaga tinggi negara terdapat pula lembaga negara lain yang tidak disebut namanya secara tegas dalam konstitusi tetapi kewenangannya ditentukan dalam konstitusi dapat menjadi subjectum litis. ${ }^{2}$ Sedangkan, Abdul Mukthie Fadjar berpandangan bahwa sengketa kewenangan lembaga negara yang dapat diselesaikan di Mahkamah Konstitusi adalah sengketa kewenangan yang melibatkan Majelis Permusyawaratan Rakyat, Presiden, Dewan Perwakilan Rakyat, Dewan Perwakilan Daerah, Badan Pemeriksa Keuangan, dan Pemerintah Daerah yang meliputi Pemerintah Daerah Provinsi dan Pemerintah Daerah Kabupaten/Kota.

\section{B. METODE PENELITIAN}

Penelitian ini merupakan penelitian yuridis normative dengan mengkaji bahan pustaka atau data sekunder. Data-data sekunder dalam penelitian ini berupa bahan hukum primer, sekunder, dan tersier. Penelitian ini menggunakan pendekatan kasus dan pendekatan peraturan perundang-undangan. Metode analisis dalam penelitian ini ialah analisis deskriptif.

\section{PEMBAHASAN}

\section{Lembaga Negara Independen dalam Sistem Ketatanegaraan}

Negara dalam menjalankan kekuasaan demi mewujudkan cita-cita negara memiliki alat kelengkapan negara berupa lembaga negara. ${ }^{3}$ Lembaga negara di Indonesia berkembang dengan beragam penyebutannya, yakni lembaga, badan, atau komisi. ${ }^{4}$ Lembaga negara umumnya menjadi materi muatan dalam konstitusi suatu negara. ${ }^{5}$

Lembaga negara berdasarkan aturan pembentuknya dibedakan menjadi lembaga negara yang dibentuk oleh Undang-Undang Dasar 1945 atau dapat disebut sebagai constitutional state organ. Rumitnya proses amandemen UUD 1945 berdampak terhadap lembaga negara yang dibentuk berdasarkan peraturan perundang-undangan. ${ }^{6}$ Lembaga negara yang dibentuk berdasarkan peraturan perundang-undangan bukan UUD 1945 dapat disebut sebagai state auxiliary organ. State auxiliary organ memiliki beberapa variasi diantaranya lembaga negara yang berada dibawah kekuasaan legislative, eksekutif, yudikatif, atau

2. Asshiddiqie, J. (2016). Perkembangan dan Konsolidasi Lembaga Negara Pasca Reformasi. Jakarta: Sinar Grafika. h. 47.

3. Ibid. h. 21 .

${ }^{4}$. Ibid. h. 22.

5. Ibid. h. 23.

${ }^{6}$. Tim Penyusun Hukum Acara Mahkamah Konstitusi. (2010). Hukum Acara Mahkamah Konstitusi. Jakarta: Sekretariat Jenderal dan Kepaniteraan Mahkamah Konstitusi Republik Indonesia. h. 4. 
merupakan lembaga negara independen. Lembaga negara independen masih selalu diperdebatkan oleh para ahli tata negara. Sebab tidak ada suatu patokan khusus yang diberikan oleh pembentuk lembaga mengenai kedudukannya di cabang kekuasaan mana.

Karakteristik yang dimiliki lembaga negara independen ialah: ${ }^{7}$

a) Independensi dalam menjalankan tugas dan fungsinya telah ditegaskan dalam peraturan pembentuknya (syarat normatif).

b) Makna independen ialah terbebas dari pengaruh, kontrol, ataupun kehendak dari cabang kekuasaan eksekutif.

c) Mekanisme pengangkatan dan pemberhentian anggota lembaga negara independen diatur secara khusus, tidak langsung berdasarkan kehendak Presiden (political appointee).

d) Kepemimpinan dalam lembaga negara independen memiliki sifat kolektif kolegial, besaran jumlah anggota bersifat ganjil dan pengambilan keputusan melalui mekanisme suara mayoritas.

e) Penguasaan kepemimpinan lembaga negara independen tidak berasal dari partai politik tertentu.

f) Periode jabatan kepemimpinan lembaga negara independen bersifat definitif, selesai masa jabatan secara bersamaan, dan untuk periode berikutnya dapat diangkat kembali maksimal 1 periode.

g) Lazimnya tujuan keanggotaan lembaga negara independen ialah sebagai bandul penyeimbang perwakilan dengan sifat nonpartisan.

Gunawan A. Tauda juga berpendapat, dalam menentukan suatu lembaga negara dapat dikatakan sebagai lembaga negara independen jika dapat memenuhi tiga unsur yakni unsur $\mathrm{a}, \mathrm{b}$, dan c. ${ }^{8}$ Dari karakteristik tersebut maka dapat dikemukakan beberapa lembaga negara yang tergolong ke dalam lembaga negara independen, yakni: ${ }^{9}$

(a) Komisi Pemilihan Umum (KPU).

Komisi Pemilihan Umum dibentuk berdasarkan Pasal 22E ayat (5) Undang-Undang Dasar 1945 jo. Undang-Undang Nomor 15 Tahun 2011 tentang Penyelenggara Pemilihan Umum. Independensi Komisi Pemilihan Umum telah dinyatakan secara tegas dalam Pasal 22E ayat (5) Undang-Undang Dasar 1945. Dalam menjalankan tugas dan fungsinya, Komisi Pemilihan Umum bersifat independen dalam arti bebas dari pengaruh dari cabang kekuasaan manapun. Hal ini terlihat dalam Pasal 3 ayat (3) Undang-Undang Nomor 15 Tahun 2011 tentang Penyelenggara Pemilihan Umum. ${ }^{10}$ Meskipun, Komisi Pemilihan Umum disebutkan secara eksplisit dalam UUD 1945, tetapi tugas dan kewenangannya diatur dalam undang-undang. Oleh karena itu, Komisi Pemilihan Umum digolongkan sebagai state auxiliary organ.

(b) Badan Pengawas Pemilu (Bawaslu).

Pengawasan pemilihan umum telah terbentuk sejak pemilu 1982 oleh Panitia Pengawas Pelaksanaan Pemilu. Kemudian, pembentukan Badan Pengawas Pemilu terjadi dengan adanya Undang-Undang Nomor 22 Tahun 2007 tentang Penyelenggara Pemilu. Seiring berjalannya dinamika pengawas pemilu, terdapat perubahan dengan terbitnya Undang-Undang Nomor 15 Tahun 2011 tentang

7. Tauda, G. A. (2011). "Kedudukan Komisi Negara Independen dalam Struktur Ketatanegaraan Republik Indonesia”. Pranata Hukum, 6 (2). h. 174.

8. Ibid. h. 175.

9. Ibid.

10. Tauda, G. A. (2012). Komisi Negara Independen. Yogyakarta: Genta Press. h. 102-104. 
Penyelenggara Pemilu. Badan Pengawas Pemilu memiliki kewenangan berupa pengawasan proses pemilu, menerima pengaduan, dan penanganan pelanggaran proses pemilu. Jika dilihat dari fungsi tersebut, maka Badan Pengawas Pemilu merupakan bagian dari kekuasaan kehakiman (yudikatif). Akan tetapi, Badan Pengawas Pemilu juga memiliki kewenangan yang identik dengan cabang kekuasaan legislatif yakni berupa menetapkan peraturan yang terkait dengan pengawasan pemilu.

(c) Komisi Pengawas Persaingan Usaha (KPPU).

Dasar pembentukan Komisi Pengawas Persaingan Usaha tertuang dalam UndangUndang Nomor 5 Tahun 1999 tentang Larangan Praktek Monopoli dan Persaingan Usaha Tidak Sehat. Komisi Pengawas Persaingan Usaha sebagai lembaga negara yang memiliki kewenangan mengatur dan juga memiliki pertanggungjawaban kepada Presiden. Sehingga, Komisi Pengawas Persaingan Usaha dapat digolongkan ke cabang eksekutif. Akan tetapi, selain kewenangan mengatur, Komisi Pengawas Persaingan Usaha juga memiliki kewenangan untuk mengawasi praktek persaingan usaha dan juga mengadili praktek persaingan usaha tidak sehat dan praktek monopoli. Tugas yang diembannya ini menjadi kewenangan kekuasaan kehakiman (yudikatif).

(d) Komisi Penyiaran Indonesia (KPI).

Komisi Penyiaran Indonesia dibentuk berdasarkan Undang-Undang Nomor 32 Tahun 2002. Komisi Penyiaran Indonesia terdiri dari Komisi Penyiaran Indonesia Pusat yang dibentuk pada tingkatan pusat dan Komisi Penyiaran Indonesia Daerah yang dibentuk ditingkat provinsi yang memiliki tugas yang bersifat koordinatif yakni berupa kebijakan secara nasional dibuat oleh Komisi Penyiaran Indonesia Pusat dan eksekusi ditingkat provinsi dijalankan oleh Komisi Penyiaran Indonesia Daerah. ${ }^{11}$ Komisi Penyiaran Indonesia memiliki kewenangan untuk menyusun peraturan dan menetapkan pedoman penyiaran. Fungsi ini identik dengan fungsi yang dimiliki oleh cabang kekuasaan legislatif. Sehingga, Komisi Penyiaran Indonesia dapat dikategorikan sebagai bagian kekuasaan legislatif. Akan tetapi selain kewenangan tersebut, Komisi Penyiaran Indonesia juga memiliki kewenangan sebagai pengawas peraturan dan pedoman perilaku penyiaran dan dapat menjatuhkan sanksi terhadap pelanggar peraturan dan pedoman perilaku penyiaran. Sehingga, jika dilihat dari kewenangan tersebut Komisi Penyiaran Indonesia dapat dikategorikan sebagai cabang kekuasaan yudikatif.

(e) Ombudsman Republik Indonesia (ORI).

Ombudsman pertama kali dibentuk dengan adanya Keputusan Presiden Nomor 44 Tahun 2000 tentang Komisi Ombudsman. Cita utama pembentukan Ombudsman oleh Gus Dur ialah ingin adanya suatu lembaga yang memiliki kewenangan untuk mengawasi kinerja dari pemerintah dan pelayanan umum dari pengadilan. ${ }^{12}$ Keberadaan Ombudsman sebagai lembaga eksternal diharapkan mampu mengontrol penyelenggara negara dan pelayanan publik. ${ }^{13}$ Kedudukan Ombudsman Republik Indonesia kemudian diperkuat dengan adanya Undang-

11. Sambodo, S. (2017). "Pengawasan Komisi Penyiaran Indonesia Daerah Riau terhadap Penyelenggaraan Penyiaran TV Kabel di Pekanbaru 2015-2016”. JOM FISIP, 4 (2). h. 2.

12. Kadarsih, S. (2010).” Tugas dan Wewenang Ombudsman Republik Indonesia Dalam Pelayanan Publik Menurut UU No. 37 Tahun 2008". Dinamika Hukum, 10 (2). h. 179.

13. Solechan. (2018). "Memahami Peran Ombudsman sebagai Badan Pengawas Penyelenggaraan Pelayanan Publik di Indonesia". Adminitrative Law \& Governance Journal, 1 (1). h. 73. 
Undang Nomor 37 Tahun 2008 tentang Ombudsman Republik Indonesia. Dalam Pasal 1 angka 1 Undang-Undang Nomor 37 Tahun 2008 tentang Ombudsman Republik Indonesia disebutkan bahwa ombudsman merupakan lembaga negara yang berwenang untuk mengawasi pelayanan publik. Ombudsman berwenang untuk menguji tindakan-tindakan terhadap norma-norma kepantasan.

Kewenangan pengawasan identik dengan kewenangan yudikatif, sehingga dapat digolongkan ke dalam cabang kekuasaan yudikatif. Akan tetapi, Ombudsman juga memiliki peran sebagai administrator yang identik dengan kewenangan dari eksekutif.

(f) Pusat Pelaporan dan Analisis Transaksi Keuangan (PPATK).

Pusat pelaporan dan Analisis Transaksi Keuangan (PPATK) dibentuk berdasarkan Undang-Undang Nomor 8 Tahun 2010 tentang Pencegahan dan Pemberantasan Tindak Pidana Pencucian Uang. Pembentukan PPATK dilatarbelakangi adanya tidak pidana pencucian uang dari hasil kejahatan. Lembaga ini bertanggung jawab kepada Presiden. Sehingga dapat dikatakan sebagai lembaga negara yang termasuk dalam kekuasaan eksekutif. Akan tetapi, lembaga ini juga memiliki kewenangan untuk mencegah dan memberantas tindak pidana pencucian uang. Kewenangan tersebut identik dengan kewenangan yudikatif.

(g) Komisi Yudisial (KY).

Komisi Yudisial dibentuk berdasarkan Pasal 24B UUD 1945 kemudian diturunkan dalam Undang-Undang Nomor 22 Tahun 2004 tentang Komisi Yudisial yang kemudian diamandemen dalam Undang-Undang Nomor 18 Tahun 2011 tentang Perubahan Undang-Undang Nomor 22 tahun 2004 tentang Komisi Yudisial. Independensi Komisi Yudisial telah ditegaskan dalam Pasal 24 UUD 1945. Kewenangan yang dimiliki oleh Komisi Yudisial ialah mengawasi integritas hakim agung.

(h) Komisi Nasional Hak Asasi Manusia (Komnas HAM).

Pembentukan Komisi Nasional Hak Asasi Manusia (Komnas HAM) terjadi pada tanggal 7 Juni 1993 melalui Keputusan Presiden Nomor 50 Tahun 1993 tentang Komisi Nasional Hak Asasi Manusia. Independensi Komisi Nasional Hak Asasi Manusia ditegaskan dalam Pasal 1 angka 7 Undang-Undang Nomor 39 Tahun 1999. Komisi Nasional Hak Asasi Manusia memiliki tugas untuk mengungkapkan berbagai bentuk pelanggaran HAM di Indonesia.

(i) Komisi Nasional Anti Kekerasan Terhadap Perempuan (Komnas Perempuan).

Komisi Nasional Anti Kekerasaan Terhadap Perempuan (Komnas Perempuan dibentuk berdasarkan Keppres Nomor 181 Tahun 1998 tentang Komisi Nasional Anti Kekerasaan Terhadap Perempuan yang kemudian diperbarui melalui Perpres No. 65 Tahun 2005 yang memiliki tujuan untuk merespon isu-isu hak-hak perempuan terkhusus terhadap permasalahan kekerasaan terhadap perempuan. Di Indonesia sendiri, lahirnya Komnas Perempuan merupakan tuntutan dari gerakan perempuan agar negara bertanggung jawab atas kekerasaan terhadap perempuan pada kerusuhan reformasi $1998 .{ }^{15}$

14. Iswandi, K. (2020). Op. Cit. h. 49.

15. Patra, R. (2012). "Efektivitas Kelembagaan Komnas Perempuan dalam Perlindungan HAM bagi Perempuan di Indonesia”. Masalah-Masalah Hukum, 41 (4). h. 596. 


\section{(j) Komisi Pemberantasan Korupsi (KPK).}

Pembentukan Komisi Pemeberantasan Korupsi dilatarbelakangi dengan adanya salah satu agenda pembenahan tata kelola pemerintahan, yakni berupa pemberantasan korupsi. ${ }^{16}$ Dasar pembentukan Komisi Pemberantasan Korupsi tertuang dalam Pasal 43 Undang-Undang Nomor 31 Tahun 1999 tentang Pemberantasan Tindak Pidana Korupsi yang kemudian ditegaskan kembali dalam Undang-Undang Nomor 30 Tahun 2002 tentang Komisi Pemberantasan Tindak Pidana Korupsi. Berdasarkan Putusan Mahkamah Konstitusi Nomor 012-016019/PUU-IV/2006 menyatakan bahwa Komisi Pemberantasan Korupsi merupakan lembaga negara yang memiliki keterkaitan hubungan dengan cabang kekuasaan kehakiman. Sedangkan Putusan Mahkamah Konstitusi Nomor 36/PUU-XV/2017 menyatakan bahwa Komisi Pemberantasan Korupsi berada di cabang kekuasaan eksekutif. Perbedaan putusan tersebut berdasarkan analisa penulis yang dilandasi oleh sifat state auxiliary organ yang disampaikan Jimly Asshiddiqie, ialah dikarenakan Komisi Pemberantasan Korupsi merupakan lembaga negara quasi yang memiliki kewenangan sebagai pengatur akan tetapi juga sebagai penegak hukum dalam bidang pemberantasan korupsi.

(k) Komisi Perlindungan Anak (KPA).

Pembentukan Komisi Perlindungan Anak didasarkan pada Keputusan Presiden Republik Indonesia Nomor 77 Tahun 2003 dan ditegaskan Pasal 74 ayat (1) Undang-Undang Nomor 35 Tahun 2014 tentang Perubahan Atas Undang-Undang Nomor 23 Tahun 2002 tentang Perlindungan Anak. Komisi Perlindungan Anak memiliki independensi yang setingkat dengan komisi negara. Komisi Perlindungan Anak memiliki tugas untuk melindungi anak-anak dari segala bentuk tindakan yang merugikan mereka. ${ }^{17}$

(1) Dewan Pers.

Dewan Pers dibentuk berdasarkan Undang-Undang Nomor 11 Tahun 1996 tentang Ketentuan-Ketentuan Pokok Pers. Dewan Pers awalnya merupakan penasehat pemerintah, tetapi kemudian beralih untuk mengembangkan kemerdekaan pers dan meningkatkan kehidupan pers nasional. ${ }^{18}$ Dengan beralihnya tugas tersebut menunjukkan adanya independensi dari Dewan Pers. Kemudian independensi Dewan Pers dituangkan dalam Pasal 15 ayat (3) Undang-Undang Nomor 40 Tahun 1999 tentang Pers.

(m) Dewan Pendidikan.

Fungsi dan tugas Dewan Pendidikan diatur dalam Peraturan Pemerintah Nomor 17 Tahun 2010 tentang Pengelolaan dan Penyelenggaraan Pendidikan. Adapun fungsi Dewan Pendidikan ditegaskan dalam Pasal 192 (2), (3), (4), dan (5). Dewan Pendidikan memiliki peran penting dalam usaha untuk memajukan dunia pendidikan baik ditingkat nasional maupun ditingkat provinsi dan kabupaten/kota. ${ }^{19}$

${ }^{16}$. Iswandi, K. (2020). Op. Cit. h. 44.

17. Lestari, D. P. (2018). "Peran Komisi Perlindungan Anak Indonesia (KPAI) dalam Perlindungan Korban Kekerasan Anak". Martabat: Jurnal Perempuan dan Anak, 2 (1). h. 319.

${ }^{18}$. Tim Penyusun. (2017). Buku Saku Wartawan. Cet. 7. Jakarta: Dewan Pers. h. 4.

19 . Hendarman. (2012). "Peran Dewan Pendidikan dalam Meningkatkan Mutu Pelayanan Pendidikan". Pendidikan dan Kebudayaan, 18 (1). h. 36. 
(n) Komisi Informasi.

Komisi Informasi terbentuk berdasarkan Undang-Undang Nomor 14 Tahun 2008 tentang Keterbukaan Informasi Publik. Dalam undang-undang tersebut juga disebutkan bahwa Komisi Informasi Pusat, Komisi Informasi Provinsi, dan jika dibutuhkan terdapat pula Komisi Informasi Kabupaten/Kota. Komisi Informasi memiliki kewenangan yang merupakan bagian dari cabang kekuasaan yudikatif yakni berupa kewenangan untuk menyelesaikan sengketa informasi publik. Selain itu, Komisi Informasi juga memiliki kewenangan administratif yang merupakan kewenangan yang lazim dimiliki oleh eksekutif.

(o) Lembaga Perlindungan Saksi dan Korban (LPSK).

Lembaga Perlindungan Saksi dan Korban (LPSK) dibentuk berdasarkan UndangUndang Nomor 13 Tahun 2006 tentang Perlindungan Saksi dan Korban. Lembaga Perlindungan Saksi dan Korban (LPSK) memiliki tanggung jawab untuk menangani pemberian perlindungan dan bantuan kepada saksi dan korban dengan kewenangan memberikan perlindungan dan bantuan kepada saksi dan korban. ${ }^{20}$

\section{Tinjauan Subjectum Litis dalam Sengketa Kewenangan Lembaga Negara di Mahkamah Konstitusi}

Ketentuan mengenai kriteria subjectum litis SKLN di Mahkamah Konstitusi, berpedoman pada ketentuan dalam Pasal 24C ayat (1) dan (2) Undang-Undang Dasar 1945. Adapun bunyi dari pasal tersebut adalah sebagai berikut.

(1) Mahkamah Konstitusi berwenang mengadili pada tingkat pertama dan terakhir yang putusannya bersifat final untuk menguji undang-undang terhadap Undang-Undang Dasar, memutus sengketa kewenangan lembaga negara yang kewenangannya diberikan oleh Undang-Undang Dasar, memutus pembubaran partai politik, dan memutus perselisihan tentang hasil pemilihan umum.

(2) Mahkamah Konstitusi wajib memberikan putusan atas pendapat Dewan Perwakilan Rakyat mengenai dugaan pelanggaran oleh Presiden dan/atau Wakil Presiden menurut Undang-Undang Dasar.

Yang kemudian diturunkan dalam Pasal 61 ayat (1) Undang-Undang Nomor 24 Tahun 2003 tentang Mahkamah Konstitusi, bahwa: "Pemohon adalah lembaga negara negara yang kewenangannya diberikan oleh Undang-Undang Dasar Negara Republik Indonesia Tahun 1945 yang mempunyai kepentingan langsung terhadap kewenangan yang dipersengketakan".

Selanjutnya dituangkan dalam Pasal 2 Peraturan Mahkamah Konstitusi Nomor 08/PMK/2006 tentang Pedoman Beracara Dalam Sengketa Kewenangan Kostitusional Lembaga Negara, yang menyebutkan:

(1) Lembaga negara yang dapat menjadi pemohon atau termohon dalam perkara sengketa kewenangan konstitusional lembaga negara adalah:

(a) Dewan Perwakilan Rakyat;

(b) Dewan Perwakilan Daerah;

(c) Majelis Permusyawaratan Rakyat;

(d) Presiden;

(e) Badan Pemeriksa Keuangan;

(f) Pemerintah Daerah; atau

20. Tuage, S. N. (2013). "Perlindungan Hukum Terhadap Saksi dan Korban oleh Lembaga Perlindungan Saksi dan Korban (LPSK)". Lex Crimen, II (2). h. 56-57.

441 I S A S I Vol. 26 No.4, Oktober - Desember 2020 
(g) Lembaga negara lain yang kewenangannya diberikan oleh UUD 1945.

(2) Kewenangan yang dipersengketakan sebagaimana dimaksud pada ayat (1) adalah kewenangan yang diberikan oleh UUD 1945.

(3) Mahkamah Agung tidak dapat menjadi pihak, baik sebagai pemohon ataupun termohon dalam sengketa kewenangan teknis peradilan (yudisial).

Subjectum litis merupakan subjek perkara sesuai dengan ketentuan yang terdapat dalam Pasal 61 Peraturan Mahkamah Konstitusi Nomor 08/PMK/2006. Sedangkan, yang dimaksud dengan syarat objectum litis merupakan syarat obyek yang dipersengketakan merupakan kewenangan konstitusional.

\section{Prospek Lembaga Negara Independen dalam Sengketa Kewenangan Lembaga Negara di Mahkamah Konstitusi}

\section{a. Perkara Nomor 030/SKLN-IV/2006}

Dalam kasus sengketa kewenangan ini melibatkan Komisi Penyiaran Indonesia dengan Presiden Republik Indonesia cq. Menteri Komunikasi dan Informatika dengan nomor perkara 030/SKLN-IV/2006. Argumentasi dari Komisi Penyiaran Indonesia ialah Komisi Penyiaran Indonesia memiliki kewenangan konstitusional dengan mendasarkan pada tafsiran Mahkamah Konstitusi yang tertuang dalam Putusan Mahkamah Konstitusi Nomor 005/PUU-I/2003 yang menyebutkan bahwa keberadaan Komisi Penyiaran Indonesia sebagai lembaga negara yang diatur dalam Undang-Undang Nomor 32 Tahun 2002 tentang Penyiaran tidak menyalahi dan tidak bertentangan dengan Undang-Undang Dasar 1945.

Komisi Penyiaran Indonesia berargumentasi bahwa ketentuan materiil pembentukan Undang-Undang Nomor 32 Tahun 2002 tentang Penyiaran berlandaskan pada Pasal 28F, Pasal 31 ayat (1), Pasal 32, Pasal 33 ayat (3), dan Pasal 36 Undang-Undang Dasar 1945. Sehingga, argumentasi dari Komisi Penyiaran Indonesia merupakan lembaga negara pelindung terhadap hak akan informasi sebagaimana tertuang dalam Pasal 28F UndangUndang Dasar 1945.

Adapun yang menjadi obyek sengketa dalam sengketa tersebut ialah kewenangan pemberian izin penyelenggara penyiaran dan pembuatan aturan dalam hal penyiaran. Kedua kewenangan tersebut yang berdasarkan dalil dari Komisi Penyiaran Indonesia merupakan kewenangan Komisi Penyiaran Indonesia. Akan tetapi, diambil alih oleh Menteri Komunikasi dan Informatika.

Mahkamah Konstitusi berpendapat bahwa Komisi Penyiaran Indonesia tidak memiliki legal standing sehingga permohonan harus dinyatakan tidak diterima (niet otvankelijk verklaard). Dasar dari putusan tersebut dikarenakan Mahkamah Konstitusi berpandangan bahwa Komisi Penyiaran Indonesia merupakan lembaga negara yang dibentuk dan memiliki kewenangan yang diberikan oleh undang-undang bukan oleh Undang-Undang Dasar 1945.

\section{b. Perkara Nomor 3/SKLN-X/2012}

Dalam sengketa tersebut, melibatkan Komisi Pemilihan Umum dengan Dewan Perwakilan Rakyat Papua dan Gubernur Papua. Dalam putusan tersebut unsur subjectum litis pemohon dan termohon, oleh Mahkamah Konstitusi dinyatakan terpenuhi. ${ }^{21}$ Hal ini menunjukkan, meskipun Komisi Pemilihan Umum bukanlah merupakan lembaga negara yang disebutkan secara langsung dalam Undang-Undang Dasar 1945 dan tidak disebutkan

21. Putusan Mahkamah Konstitusi Nomor 3/SKLN-X/2012, h. 170. 
dalam Pasal 2 Peraturan Mahkamah Konstitusi Nomor 08/PMK/2006. Akan tetapi, Komisi Pemilihan Umum merupakan lembaga negara independen. Dalam artian, Komisi Pemilihan Umum tidak disebutkan secara langsung dalam Undang-Undang Dasar 1945 dikarenakan dalam Pasal 22E ayat (5) pada frasa "komisi pemilihan umum" yang diartikan oleh beberapa pakar hukum tata negara merupakan bentuk jamak, tidak tertuju pada satu lembaga penyelenggara pemilu.

Sengketa dalam perkara Nomor 3/SKLN-X/2012 terkait dengan kekhususan yang dimiliki Provinsi Papua dalam bidang pemerintahan. Latar belakang terjadinya sengketa dikarenakan adanya ketidakterkaitan UU Otonomi Khusus dengan UU Pemerintah Daerah yang berimplikasi rancunya proses penyelenggaraan Pemilihan Gubernur dan Wakil Gubernur Papua. ${ }^{22}$

Dari segi objectum litis pada putusan tersebut yakni berupa kewenangan penyelenggaraan Pemilu Gubernur dan Wakil Gubernur di Papua yang merupakan daerah otonomi khusus. Dalam hal ini, Mahkamah Konstitusi berpendapat bahwa kewenangan yang dipersengketakan dalam SKLN tidak harus merupakan kewenangan yang disebutkan secara eksplisit dalam UUD 1945, akan tetapi, juga termasuk kewenangan delegasi yang bersumber dari kewenangan atribusi yang disebutkan dalam UUD 1945.

Mahkamah berpendapat bahwa pemohon dan termohon memiliki legal standing untuk mengajukan permohonan a quo atau dapat dikatakan bahwa pemohon dan termohon memenuhi syarat subjectum litis. Dengan demikian, Mahkamah Konstitusi memberikan putusan, yakni menolak eksepsi Termohon I dan mengabulkan permohonan Pemohon. Dua putusan tersebut kami tuangkan ke dalam tabel berikut:

Tabel 1. Analisis Putusan MK No 030/SKLN-IV/2006 dan Putusan MK No 3/SKLN-X/2012

\begin{tabular}{|c|c|c|}
\hline Variabel & 030/SKLN-IV/2006 & 3/SKLN-X/2012 \\
\hline Pemohon & Komisi Penyiaran Indonesia & Komisi Pemilihan Umum \\
\hline Termohon & $\begin{array}{l}\text { Presiden Republik Indonesia } \\
c q \text { Menteri Komunikasi dan } \\
\text { Informatika. }\end{array}$ & $\begin{array}{l}\text { Pemerintahan } r \text { Provinsi } \\
\text { Papua, yakni Gubernur } \\
\text { Papua dan DPRD Provinsi } \\
\text { Papua. }\end{array}$ \\
\hline Status Lembaga Pemohon & Lembaga Negara Independen & $\begin{array}{ll}\text { Lembaga } & \text { Negara } \\
\text { Independen } & \end{array}$ \\
\hline Status Lembaga Termohon & Constitutional state organ & Constitutional state organ \\
\hline Subjectum Litis & Tidak Terpenuhi & Terpenuhi \\
\hline Objectum Litis & $\begin{array}{l}\text { Kewenangan pemberian izin } \\
\text { penyiaran. }\end{array}$ & $\begin{array}{l}\text { Kewenangan } \\
\text { menyelenggarakan } \\
\text { pemilukada di daerah } \\
\text { otonomi khusus. }\end{array}$ \\
\hline Ratio Legis MK & $\begin{array}{l}\text { Komisi Penyiaran Indonesia } \\
\text { merupakan lembaga negara } \\
\text { yang dibentuk dan } \\
\text { kewenangannya diberikan } \\
\text { oleh undang-undang bukan } \\
\text { UUD 1945. Dengan } \\
\text { demikian } \quad \text { KPI }\end{array}$ & $\begin{array}{l}\text { Terpenuhinya syarat } \\
\text { subjectum litis dengan } \\
\text { kriteria baik pemohon dan } \\
\text { termohon memiliki legal } \\
\text { standing. Kemudian juga } \\
\text { terpenuhinya syarat } \\
\text { objectum litis yakni berupa }\end{array}$ \\
\hline
\end{tabular}

22. Mochtar, Z. A. (2016). Lembaga Negara Independen, Dinamika Perkembangan dan Urgensi Penataannya Kembali Pasca-Amandemen Konstitusi. Jakarta: Rajawali Press. h. 142-143. 
memenuhi kriteria subjectum

litis SKLN di Mahkamah

Konstitusi. kewenangan

dalam

penyelenggaraan pemilihan umum. Akan tetapi, dalam putusan tersebut terdapat dissenting opinion yakni oleh Hakim Konstitusi Maria Farida dan Hamdan Zoelva.

\begin{tabular}{|c|c|c|}
\hline Amar Putusan & Tidak dapat diterima & $\begin{array}{l}\text { 1. Menolak eksepsi } \\
\text { Termohon I. } \\
\text { 2. Mengabulkan } \\
\text { permohonan Pemohon. }\end{array}$ \\
\hline
\end{tabular}

Sumber: www.mkri.id

Dari tabel tersebut terlihat bahwa meskipun keduanya merupakan lembaga negara independen, tetapi tidak semuanya jika terjadi sengketa dapat diselesaikan di Mahkamah Konstitusi. Sengketa kewenangan yang melibatkan lembaga negara independen yang dapat diselesaikan di Mahkamah Konstitusi ialah sengketa yang melibatkan lembaga negara yang memiliki kewenangan konstitusional. Meskipun tidak disebutkan dengan jelas nama lembaganya tetapi kewenangan konstitusionalnya telah disebutkan dengan jelas.

Argumentasi tersebut diatas sejalan dengan pendapat dari Jimly Asshiddiqie yang menyatakan bahwa sengketa yang melibatkan lembaga negara yang bukan lembaga negara utama (constitutional state organ) dapat diselesaikan di Mahkamah Konstitusi dengan syarat lembaga negara tersebut memiliki constitutional importance. ${ }^{23}$ Yang dapat menentukan lembaga negara tersebut memiliki constitutional importance atau tidak ialah hakim konstitusi. Hal ini dikarenakan Mahkamah Konstitusi sebagai the enforcer, ${ }^{24}$ the guardian or the interpreter of the constitution. ${ }^{25}$

Dilihat dari tugas dan kewenangan Komisi Penyiaran Indonesia ialah merupakan perpanjangan tangan dari cabang kekuasaan eksekutif, meskipun merupakan lembaga negara independen. Sehingga lembaga negara yang dapat menyelesaikan sengketa tersebut ialah lembaga negara pembentuk dalam hal ini Presiden dan DPR. ${ }^{26}$ Akan tetapi, penulis lebih condong penyelesaian antara Komisi Penyiaran Indonesia dan Menteri Komunikasi dan Informatika dapat diselesaikan oleh Presiden. Hal ini dikarenakan bagaimanapun juga kewenangan izin penyiaran ialah kewenangan eksekutif (kewenangan Presiden) sehingga Presiden dapat menentukan lembaga negara mana yang diberikan otoritas untuk menerbitkan izin penyiaran.

\section{PE N T U P}

Berkembangnya lembaga negara independen di Indonesia memberikan dampak terhadap efektivitas lembaga negara independen yang dibentuk. Selain itu, beberapa lembaga negara independen terlibat sengketa kewenangan dengan lembaga negara lainnya. Seperti kasus sengketa kewenangan antara Komisi Penyiaran Indonesia dengan Presiden

23. Asshiddiqie, J. (2016). Op. Cit. h. 104.

${ }^{24}$. Pigome, M. (2011). "Implementasi Prinsip Demokrasi dan Nomokrasi dalam Struktur Ketatanegaraan RI Pasca Amandemen UUD 1945”. Dinamika Hukum, 11 (2). h. 335.

25. Simamora, J. (2015). "Comparison of Constitutional Court Authority between Indonesia and South Korea”. Dinamika Hukum, 15 (3). h. 332-333.

26. Tim Penyusun Hukum Acara Mahkamah Konstitusi, 2010, Op. Cit. h. 158. 
Republik Indonesia $c q$. Menteri Komunikasi dan Informatika. Sengketa ini didaftarkan di Mahkamah Konstitusi dengan Nomor Perkara 030/SKLN-IV/2006 dengan obyek sengketa ialah kewenangan pemberian izin penyiaran. Mahkamah Konstitusi memberikan putusan bahwa perkara ini tidak dapat diterima. Kasus sengketa kewenangan berikutnya melibatkan Komisi Pemilihan Umum dengan Pemerintah Provinsi Papua dalam hal ini Gubernur Papua dan DPRD Provinsi Papua. Sengketa ini diregister dengan Nomor Perkara 3/SKLN-X/2012 dengan obyek sengketa penyelenggaraan pemilukada di daerah otonomi khusus dalam hal ini Provinsi Papua. Keduanya merupakan kasus sengketa yang melibatkan lembaga negara independen. Akan tetapi, tidak semuanya memenuhi syarat subjectum litis di Mahkamah Konstitusi. Hal ini dikarenakan Komisi Pemilihan Umum merupakan lembaga negara independen. Sedangkan, Komisi Penyiaran Indonesia merupakan lembaga negara independen yang dibentuk berdasarkan undang-undang. Dengan demikian, tidak semua sengketa kewenangan yang melibatkan lembaga negara independen dapat diselesaikan di Mahkamah Konstitusi. Dilihat dari tugas dan kewenangan Komisi Penyiaran Indonesia ialah merupakan perpanjangan tangan dari cabang kekuasaan eksekutif, meskipun merupakan lembaga negara independen. Sehingga lembaga negara yang dapat menyelesaikan sengketa tersebut ialah lembaga negara pembentuk dalam hal ini Presiden dan DPR.

\section{DAFTAR PUSTAKA}

\section{Jurnal}

[1] Eddyono, L. W., (2010), "Penyelesaian Sengketa Kewenangan Lembaga Negara oleh Mahkamah Konstitusi”, Jurnal Kostitusi, 7 (3): 1-48.

[2] Hendarman. (2012). "Peran Dewan Pendidikan dalam Meningkatkan Mutu Pelayanan Pendidikan", Jurnal Pendidikan dan Kebudayaan, 18 (1).

[3] Kadarsih, S. (2010). "Tugas dan Wewenang Ombudsman Republik Indonesia dalam Pelayanan Publik Menurut UU No. 37 Tahun 2008”. Jurnal Dinamika Hukum, 10 (2).

[4] Lestari, D. P. (2018). "Peran Komisi Perlindungan Anak Indonesia (KPAI) dalam Perlindungan Korban Kekerasan Anak". Jurnal Martabat: Jurnal Perempuan dan Anak, 2 (1).

[5] Patra, R. (2012). "Efektivitas Kelembagaan Komnas Perempuan dalam Perlindungan HAM bagi Perempuan di Indonesia”. Jurnal Masalah-Masalah Hukum, 41 (4).

[6] Pigome, M. (2011). "Implementasi Prinsip Demokrasi dan Nomokrasi dalam Struktur Ketatanegaraan RI Pasca Amandemen UUD 1945". Jurnal Dinamika Hukum, 11 (2).

[7] Sambodo, S. (2017). "Pengawasan Komisi Penyiaran Indonesia Daerah Riau Terhadap Penyelenggaraan Penyiaran TV Kabel di Pekanbaru 2015-2016". Jurnal JOM FISIP, 4 (2).

[8] Simamora, J. (2015). "Comparison of Constitutional Court Authority between Indonesia and South Korea". Jurnal Dinamika Hukum, 15 (3).

[9] Solechan. (2018). "Memahami Peran Ombudsman sebagai Badan Pengawas Penyelenggaraan Pelayanan Publik di Indonesia". Adminitrative Law \& Governance Journal, 1 (1).

[10] Tauda, G. A. (2011). "Kedudukan Komisi Negara Independen dalam Struktur Ketatanegaraan Republik Indonesia”. Jurnal Pranata Hukum, 6 (2).

[11] Tuage, S. N. (2013). "Perlindungan Hukum Terhadap Saksi dan Korban Oleh Lembaga Perlindungan Saksi dan Korban (LPSK)". Jurnal Lex Crimen, II (2). 


\section{Buku}

[12] Asshiddiqie, J. (2016). Perkembangan dan Konsolidasi Lembaga Negara Pasca Reformasi. Jakarta: Sinar Grafika.

[13] Mochtar, Z. A. (2016). Lembaga Negara Independen, Dinamika Perkembangan dan Urgensi Penataannya Kembali Pasca-Amandemen Konstitusi. Jakarta: Rajawali Press.

[14] Tauda, G. A. (2012). Komisi Negara Independen. Yogyakarta: Genta Press.

[15] Tim Penyusun Hukum Acara Mahkamah Konstitusi. (2010). Hukum Acara Mahkamah Konstitusi. Jakarta: Sekretariat Jenderal dan Kepaniteraan Mahkamah Konstitusi Republik Indonesia.

[16] Tim Penyusun. (2017). Buku Saku Wartawan. Cet. 7. Jakarta: Dewan Pers.

\section{Skripsi}

[17]Iswandi, K. (2020). Penyelesaian Sengketa Kewenangan State Auxiliary Organ di Indonesia. Skripsi. Universitas Muhammadiyah Yogyakarta. 